\title{
Social determinants of health that permeate the mental suffering of children on the french-brazilian border
}

\author{
Determinantes sociais de saúde que permeiam o sofrimento mental de crianças na fronteira franco-brasileira
}

Determinantes sociales de la salud que permiten el sufrimiento mental de los niños en la frontera franco-brasileña

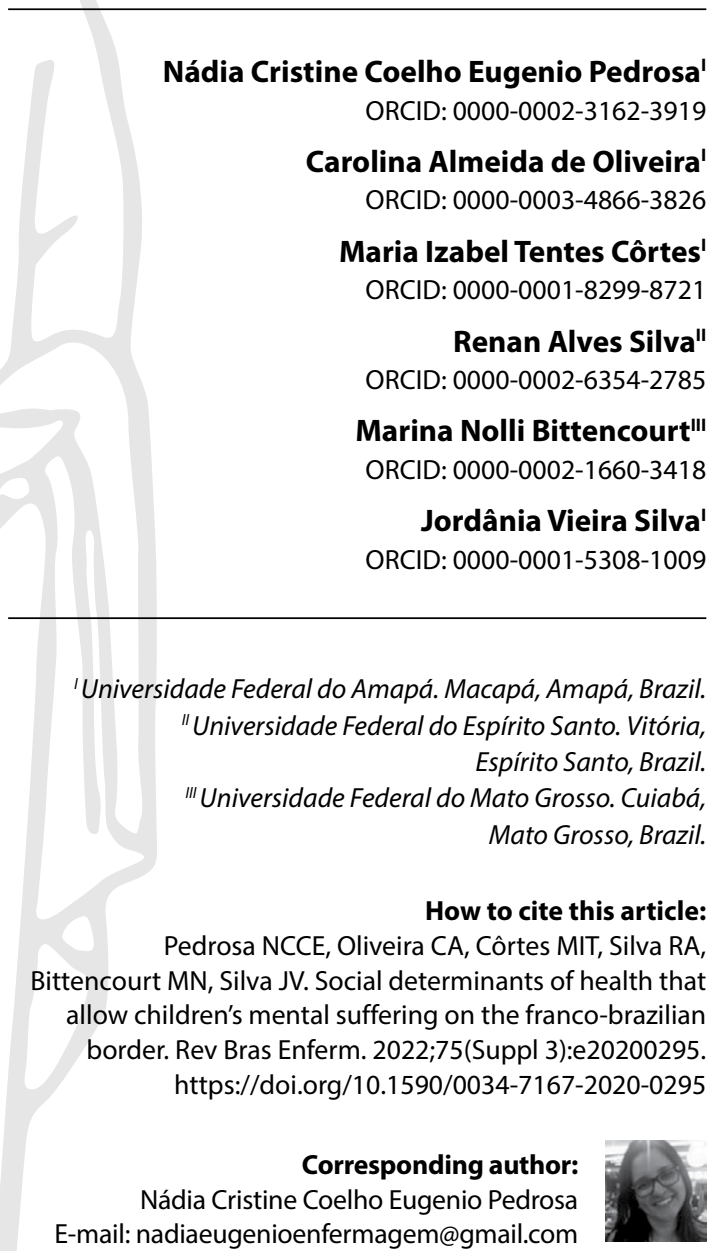

EDITOR IN CHIEF: Dulce Barbosa ASSOCIATE EDITOR: Priscilla Valladares Broca

Submission: 06-03-2020 Approval: 04-18-2021

\begin{abstract}
Objectives: to understand the determinants involved in the mental suffering of schoolchildren on the French-Brazilian border. Methods: a qualitative study was conducted with children from 6 to 12 years of age from four State schools in the municipality of Oiapoque, located on the French-Brazilian border. The data were obtained through interviews, analyzed by the IRAMUTEQ software, and interpreted in the light of the Dahlgren and Whitehead's social determinants of health model. Results: data indicate that the mental suffering experienced by children, especially characterized by anxious symptoms, such as concern of becoming fat and worries, were permeated by social situations that children went through daily, such as family abandonment, domestic violence, and bullying. Final Considerations: social determinants can be predictors of mental suffering in children, especially in environments of extreme vulnerability, such as the border, in a context of financial difficulties, domestic violence, and absence of parenting.

Descriptors: Child; Mental Health; Social Determinants of Health; Border Areas; Anxiety
\end{abstract}

\section{RESUMO}

Objetivos: compreender os determinantes envolvidos no sofrimento mental de crianças escolares na fronteira franco-brasileira. Métodos: estudo qualitativo realizado com crianças de 6 a 12 anos, de quatro escolas estaduais do município de Oiapoque, localizadas na fronteira franco-brasileira. Os dados foram obtidos por meio de entrevistas, analisados pelo software IRAMUTEQ e interpretados à luz do modelo de determinantes sociais da saúde de Dahlgren e Whitehead. Resultados: os dados apontam que o sofrimento mental vivenciado pelas crianças, especialmente caracterizado por sintomas ansiosos, como medo de ficar gordo e preocupação, eram permeados por situações sociais pelas quais as crianças passavam no dia a dia, como abandono familiar, violência doméstica e bullying. Considerações Finais: os determinantes sociais podem ser preditores do sofrimento mental em crianças, sobretudo em ambientes de extrema vulnerabilidade, como o de fronteira, em que permeiam situações relacionadas a dificuldades financeiras, violência doméstica e ausência de parentalidade. Descritores: Criança; Saúde Mental; Determinantes Sociais da Saúde; Áreas de Fronteira; Ansiedade.

\section{RESUMEN}

Objetivos: comprender los determinantes involucrados en el sufrimiento mental de los escolares de la frontera franco-brasileña. Métodos: estudio cualitativo realizado con niños de 6 a 12 años de cuatro escuelas públicas del municipio de Oiapoque, ubicadas en la frontera franco-brasileña. Los datos fueron obtenidos a través de entrevistas, analizados por el software IRAMUTEQ e interpretados a la luz del modelo de determinantes sociales de la salud de Dahlgren y Whitehead. Resultados: los datos muestran que el sufrimiento mental experimentado por los niños, especialmente caracterizado por síntomas ansiosos, como el miedo a engordar y la preocupación, estuvo permeado por situaciones sociales por las que atravesaron los niños en su vida diaria, como el abandono familiar, la violencia doméstica y intimidación. Consideraciones Finales: los determinantes sociales pueden ser predictores de sufrimiento mental en los niños, especialmente en entornos de extrema vulnerabilidad, como el de frontera, en un contexto de dificultades económicas, violencia doméstica y ausencia de paternidad.

Descriptores: Niño; Salud Mental; Determinantes Sociales de la Salud; Zonas Fronterizas; Ansiedad. 


\section{INTRODUCTION}

According to the World Health Organization (WHO), the social determinants of Health (SDOHs) are related to the conditions in which people are born, grow, work, live and age; and to the extent of forces and systems that shape the circumstances of everyday life ${ }^{(1)}$. Thus, the SDOHs involve specific characteristics of the social context that can affect health and how these social conditions can influence it ${ }^{(2)}$.

Among the models that study the SDOHs, the Dahlgren and Whitehead's model of $1991^{(3)}$, adopted in Brazil by the National Commission on Social Determinants of Health, explains how social interactions, at the individual, economic, cultural, and environmental levels, generate inequalities in health. Individually, characteristics such as age, gender, behavior, and lifestyle are presented, which contribute to exposure to health risk factors such as drug use and anorexia, which are strongly influenced by SDOHs. At the level of social and community interactions, social cohesion and the strengthening of networks are shown as health-generating elements in society. At the level of living and working conditions, there are unsanitary working conditions, unemployment, poverty, scarce access to essential services, which put people at a social disadvantage. Finally, the last level involves economic, cultural, and environmental conditions, as well as the promotion of Sustainable Development ${ }^{(3)}$. To that end, a systematic review of the literature reports that, when the imbalance occurs at one of these levels involving the $\mathrm{SDOH}$, there may be direct interference in the reality known by individuals, with a propensity for infectious diseases, mental and eating disorders, use of psychoactive substances, the practice of self-mutilation, early and unprotected sexual activity, and worsening the chances of early pregnancy among girls $\mathrm{s}^{(4)}$.

Regarding the interference of SODHs in the mental health of children, at the social level, research indicates that degrading conditions that children are exposed, such as parental abandonment, are harmful to psychosocial development and can generate mental health problems $\mathrm{s}^{(5)}$. Parental abandonment occurs for several reasons, among which is the low employment opportunity, which becomes a reality for families living in border regions, such as the case of the French-Brazilian border ${ }^{(6)}$, where only $7.8 \%$ of the population are hired employees and the value of the Human Development Index is below the national average $(0.658 \text { and } 0.699 \text {, respectively })^{(7)}$.

Studies also show that, in addition to parental abandonment, to which children living in these borders are exposed and individually generates consequences, such as loneliness and low self-esteem, there is the development of symptoms of anxiety and depression ${ }^{(8)}$. In addition, misery causes them to be exposed to moral, sexual abuse, and domestic violence, determinants that are also associated with the development of psychopathological symptoms ${ }^{(9)}$ and even post-traumatic stress ${ }^{(10)}$.

By considering the perspective now presented and the Sustainable Development Goals of the Population, proposed by the United Nations, this study will allow the strengthening of Nursing in the process of promoting global health. It is because, for we can achieve equity and response to the health needs of populations in greater vulnerability, nursing must consider the individual and population determinants of health and engage in a practice of respect for the dignity and Human Rights, to meet the priorities of global health ${ }^{(11)}$ and promote the sustainable development of the population.
Thus, considering that the French-Brazilian border has as a migratory attraction the clandestine mines and suffers from problems such as prostitution, high unemployment rates, low schooling, and lack of basic sanitation ${ }^{(7,12)}$, people living in these regions become exposed, in a more expressive way, to negative SDOHs when compared to those living in other areas of the country ${ }^{(13)}$; and children because they are in full biopsychosocial development, become the most vulnerable to these social determinants, which put them in a situation of mental suffering. Therefore, knowing these SDOHs will allow nurses and the health team to propose health promotion and prevention actions as well as policies informed by the evidence indicated in search of a dignified life and sustainable development of this population. Thus, we asked the question: What are the social determinants involved in the mental suffering of schoolchildren on the French-Brazilian border?

\section{OBJECTIVES}

To understand the determinants involved in the mental suffering of schoolchildren on the French-Brazilian border.

\section{METHODS}

\section{Ethical aspects}

We respected the ethical aspects following the standards for research with human beings, the National Health Council Resolution, No. 466, of December 12, 2012. The approval was obtained according to the Opinion, dated August 22, 2016, of the Research Ethics Committee of the Federal University of Amapá.

\section{Study design}

This is a qualitative study, with thematic content analysis, descriptive and exploratory, guided by the COREQ protocol, having as theoretical reference the model of social determinants of health of Dahlgren and Whitehead ${ }^{(3)}$.

\section{Collection and organization of data}

The study was conducted in the municipality of Oiapoque, located on the trans-Amazonian border, in the northernmost part of the State of Amapá (AP), Brazil, about $600 \mathrm{~km}$ from the capital, Macapá, where it borders the French overseas territory, French Guiana.

Data collection occurred from August to September 2018 and was carried out in four Municipal schools located in the urban area of Oiapoque. The interviews were carried out by prior appointment with the school management, in a reserved room, with an average duration of 25 minutes and only with the presence of the researcher and the interviewee (child).

\section{Sample criteria of inclusion and exclusion}

This study involved 264 children, aged 6 to 12 years, who attend from 1 st to 6 th grade in four Municipal Public Schools of Oiapoque. The children were selected for convenience, considering the saturation of the data related to the social determinants that permeated the children's statements with evidence of 
psychopathological symptoms by the applied scale. We decided on this approach as a result of the development of parallel convergent mixed study with these children.

We excluded children who were not present in the selected schools during the data collection period and who were not in the age group of 6 to 12 years of age were excluded from the study.

\section{Work steps}

After authorization from the principals of the schools selected by sweepstake, we agreed on the date for delivery of the free and informed consent (FIC) with the school management for each child to take it to the responsibility to sign. On the agreed day for the interviews, only the students with the FIC correctly completed and signed by the respondents were invited to participate in the survey and who agreed to participate in the survey by signing the consent form (CF). The interviews took place during class hours, in a private room provided by the school.

\section{Methodological procedures}

The interview consisted of questions about sociodemographic data and the use of the Scale of Identification of Psychopathological Symptoms in Schoolchildren (SIPSS), based on the children's statements. The SIPSS is a scale aimed at children aged 6 to 12 years, composed of 23 items, 19 with negative sense and 4 with positive sense related to mood, eating patterns, use/abuse of psychoactive substances, anxiety, social behaviors, and active/ motor attention of the child, with the child having three response options: always, sometimes, never. The scale was validated, showing the reliability of the items of 0.97 and Cronbach's alpha of $0.67^{(14)}$.

Through the negative response to the positive items and positive to the negative items of the SIPSS, the interviewer asked the child to talk more about the symptoms experienced by him: "Tell me more about it...".

We recorded the speeches on a digital device, transcribed by the researcher, and then analyzed. The participants were randomly coded with the letter $C$ (child), followed by the speech number to ensure anonymity.

\section{Data analysis}

We typed and analyzed the quantitative data on the Excel 2018 program, referring to sociodemographic variables and responses to SIPSS items, using the descriptive analysis technique through simple frequency calculation.

We transcribed and organized the collected interviews in a single corpus, submitted to the Iramuteq software (Interface de $R$ pour les Analyses Multidimensionelles De Textes et de Questionnaires), and interpreted in light of the theoretical framework of social determinants in health ${ }^{(3)}$.

The iRaMuTeQ software enables five forms of analysis: classical textual statistics, group specificity search, descending hierarchical classification, similarity analysis, and word cloud. In this study, we chose to use the word cloud and the descending hierarchical classification (DHC), which allows us to group the words and organized them graphically, according to the frequency with which they appeared.
In addition, this mode allowed an easier identification, through a single file, with a corpus that brought together the texts originated by the interviews. We performed the lexical analysis, based on the most frequent words provided by the text segments ${ }^{(15)}$.

For the construction of the dendrogram and the subsequent analysis, we considered the words with a frequency equal to or greater than the average frequency (i.e. greater than or equal to 3 ), with $\times 2$ greater than or equal to 2.0 , and $p$ of significance less than or equal to 0.0001 . We described each class by the most significant (most frequent) words and their associations with the class (chisquare). By Descending Hierarchical Classification (DHC), the analysis and discussion of the classes accompanied the dendrogram with the partitions, and the reading was carried out from left to right.

\section{RESULTS}

The children who participated in the study were mostly female (50.8\%), born in the municipality of Oiapoque-AP $(62.5 \%)$, were between 8 and 10 years old (39.4\%), and were enrolled in the $3^{\text {rd }}$ and $4^{\text {th }}$ year of elementary school $(46.5 \%)$. Most of them reported performing physical activity three or four times a week $(43.9 \%)$, having a family income of zero to five minimum wages (89\%), no family member in psychiatric treatment (100\%), and no family members who abused psychoactive substances (91.6\%).

Regarding the SIPSS, the negative items most positively answered by schoolchildren were those related to mood, anxiety, and eating patterns: "I feel anxious or too worried about things that happen to me"(43.2\%), "I am sad or want to cry most of the time" (53.3\%),"I am afraid of gaining weight and becoming fat" $(43.5 \%)$. Therefore, they were the ones that generated the most speeches by the children.

In the qualitative analysis, the word cloud method pointed to the word "stay" as the most frequent in the corpus, followed by the word "concern" (Figure 1). For textual data analysis, we divided the corpus into four Units of Elementary Contexts (UEC), with 94 text segments, 324 distinct forms, and 1,218 occurrences of words in the text.

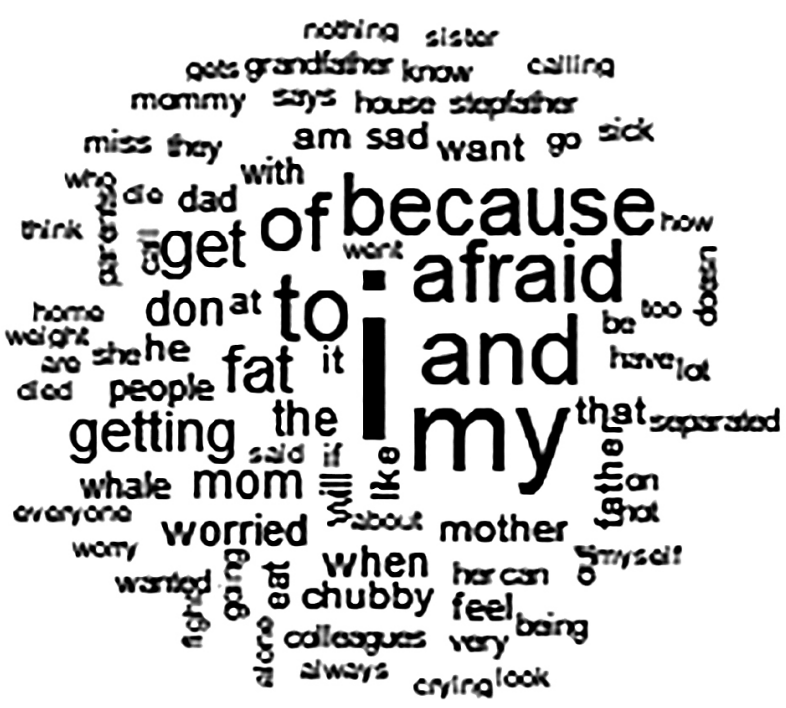

Figure 1 - Word cloud resulting from the frequency of the speeches of schoolchildren obtained from the corpus 
After processing the corpus in the program, we interpreted the meanings of the words in the students' speeches. Thus, the word "stay"made sense of "remain", explaining the concern of schoolchildren in staying/ remaining in certain contexts that generate suffering, such as "getting" fat and suffering bullying; and "being" worried about problems experienced in the family environment. The word "concern" expressed the feeling of danger or threat in the face of the problems experienced in the family and school environment; and was also associated with the "concern" of being bullied by peers and being excluded, in addition to the "concern" of getting fat.

In the process of data collection, through the word cloud, we observed other prominent lexicons, such as: "because,"'not,"'fat,"'mother," "father,"'worried."

Not -The word can be related to the denial of schoolchildren in the face of various situations, denial about the concern of gaining weight, separation from parents, denial about living away from parents and siblings, denial about violence and sexual abuse, denial about hunger and misery.

Because - Expression is used by schoolchildren to explain the reason/cause of the facts happening.

Concern - A word often used by schoolchildren, which can be associated with concern, anxiety, a state of danger, something that generates panic.

Fat - It has a direct relationship to being overweight, obese person, accumulation of body fat, the figure of "big" person; means social exclusion and health problems for schoolchildren.

Mother - Associated with the maternal figure, affective, opinionforming, synonymous with love, a heaven for the child, coziness.

Father - Associated with the father figure, an example to be followed, a person who makes child feel safe and comfortable.

Concerned - It has a direct relationship with the concern and apprehension exerted by schoolchildren, when they report facts lived in the family and school environment. Many have shown to be thoughtful and problem-ridden.

The lexical analysis presented the interclass relations as following: first, the corpus was divided into two subgroups, and one subgroup was divided into two, resulting in Classes 4 and 2; and the other subgroup was also subdivided into two, resulting in Classes 3 and 1. It means that Classes 4 and 2 have a greater proximity relationship, in the same way as Classes 3 and 1, although, among these subgroups, there is little proximity relationship between the classes (Figure 2).

Thus, Class 4 points to the concern of schoolchildren from family situations, and Class 2 shows their sadness due to family problems. Class 3 demonstrates the anxiety of schoolchildren generated by imposed social standards, and Class 1 shows their concern of not meeting body standards.

By analyzing Class 4, Concern arising from family situations, we found that many participants presented feelings of sadness, anxiety, and concerns arising from family situations, with the most frequent words: "stepfather," "mother," "quarrel," "worried," and "much." The lines that emerged in Class 4 are evidenced below:
I get worried when my mom fights with my stepfather. (C28)

My stepfather threatens my mother with death, so I get very worried. (C19)

Sometimes my mother and stepfather quarrel and argue. (C48)

I'm afraid mom's gonna get arrested when she goes to the mine. (C25)

I miss my father, mom, and grandpa, my father is a fisherman and leaves me alone. (C42)

Regarding Class 2, Sadness caused by family problems, the highlighted words were:"sad,"'father,"'grandfather,"'worry,"'mom," "home," "live."These are the speeches that explain it:

I've been abused by my grandfather, I feel contempt for my mother, I think she doesn't like me. (C52)

I went to a man's house with some colleagues and he gave money to us, then I did not go there anymore because my grandfather forced me. (C17)

My father does look at me anymore, lives in Caiena, and I miss him. My mother said she's going to put him to justice. (C16)

I get worried because when my dad drinks, he goes home and wants to assault mom, and I come to school worried. (C22)

I get worried and cry because mom has nothing to eat; I'm having lunch at my aunt's house because there is nothing to eat in my house. (C24).

Class 3, Anxiety generated by social standards imposed by society, points to the concern of humiliation or health problems due to weight gain. The most frequent words were "to get fat," "to want" and "not", which can be learned through the speeches of schoolchildren:

Idon't want to get fat, because the fat person might have problems if he gets fat. (C88)

I'm afraid of getting fat and people tease me. (C63) 
In Class 1, Concern of not meeting body standards, the words "concern," "fat," "equal," "talk," and "stay" were highlighted, presenting the anxiety of children generated by the concern of not meeting the standards imposed by society, which is evident in the responses of schoolchildren.

I'm afraid of getting fat, because everyone says that when you get fat, you get ugly. (C64)

I'm afraid I'm gonna get fat just like the people on TV. (C81)

\section{DISCUSSION}

The study pointed out that the social determinants related to the mental suffering of the participating children were strongly linked to the social/family level and the working conditions of the parents, which generated SDOHs such as family abandonment, domestic violence, bullying, hunger, and sexual abuse. Thus, the data showed that when children are exposed to negative SDOHs, these generate mental suffering to them and, consequently, some risk behaviors since studies indicate that children exposed to negative social situations end up becoming more vulnerable to the development of mental disorders, such as depression, alcohol abuse, and other drugs, among other negative behaviors ${ }^{(4)}$.

We found that much of the feeling of sadness and concern of the children in this survey was related to some $\mathrm{SDOH}$, related to living and working conditions, such as lack of employment, since parents start migrating to other places, such as French Guiana and mines near Oiapoque, in search for better living conditions. Concerning this, we observed that, although the Human Development Index (HDI) of the municipality of Oiapoque-AP has increased from 0.50 to 0.658 , from 1991 to $2010^{(7)}$, with growth related to the implementation of public social service agencies, the municipality still presents several difficulties regarding the collection of taxes, since the secondary sector/industry has no significance for the city's economy but to the informal sector, such as the illegal mining, which does not generate taxes. In addition, the municipality presents structural and logistical problems that hinder regular and constant socio-economic growth, as well as limit the development of inhabitants and creation of jobs ${ }^{(6)}$.

In addition, the survey emphasizes that the issues of clandestinity and illegal mining cause a lot of tension in the border area of Oiapoque-AP since Brazilians from impoverished regions are attracted to the French-Brazilian border, searching for the so-called "El Dorado." However, the border area is noted by issues of smuggling, human trafficking, child sexual exploitation, sex tourism, among other problems that show the fragility of the border ${ }^{(11)}$, a fact evidenced by the talk of abuse and sexual harassment among children.

Therefore, the "mining economy" mobilizes people and stimulates monetary circulation, but this economic scenario can be considered contradictory, since the gold cycle does not allow migration of people with skilled labor, and even less so with cultural capital. In addition, the financial resources invested in the "mining economy" do not remain in the Oiapoque region, and the human resources attracted are precarious ${ }^{(6)}$. It causes unemployment and the search for work to result in severing family ties between parents and children and, consequently, affect the mental health and well-being of children who experience this social environment, who become lonely, vulnerable to the care of third parties ${ }^{(5)}$, a fact also evidenced in the statements of schoolchildren.

Throughout life, children may present difficulties at the individual level, such as those related to low self-esteem, anxiety symptoms, and the development of symptoms of depression ${ }^{(8)}$, which need to be treated otherwise can generate high costs to society due to the treatment of mental disorders ${ }^{(16)}$. And, although these conditions are influenced by individual situations, parental abandonment, as a social and work-related condition, can also cause serious harm to children who suffer from the absence of their father or mother. This fact exposes them to embarrassing situations, often making them victims of sexual abuse and putting them in experiences of domestic violence, alcoholism, financial difficulty, hunger, and misery ${ }^{(8)}$.

Thus, monitoring psychopathological symptoms during childhood, especially in places where children are exposed to negative $\mathrm{SDOHs}$, is essential to prevent the occurrence of severe impacts on their development and to subsidize public policies that propose strategies capable of circumventing possible negative impacts ${ }^{(6)}$.

The data also indicate that the mental suffering caused by the financial difficulties experienced by schoolchildren sometimes goes unnoticed by the family. We noted the discontent of some children when they talked about the lack of food in their homes and the anguish of leaving family members at home without food, concerns that hinder the concentration in the classrooms. It is even more worrying because this anguish - resulting from the often persistent misery - puts these children at risk of developing mental disorders because they live in a place where opportunities are few and the possibility of recovering is scarce ${ }^{(17)}$. Therefore, we warn once again to strengthen both social policies aimed at the different levels related to the SODHs of this child population and health education activities that can not only promote the socio-emotional health of these children but also generate income for families.

Regarding the children's statements from positive responses to items related to eating patterns, we observed the potential influence of the media on the individual identification of the body patterns of schoolchildren and the desire to have a perfect body and be well-seen by society, which may cause suffering in these children - this is an SDOHs at the individual level triggering problems related to the mental health of this public. Not only the dissatisfaction that the person has with the body is a serious risk for the development of eating disorders, but also the media is one of the factors since it causes young people to reinforce this thought of dissatisfaction with the body ${ }^{(18)}$.

In addition, bullying can also be a serious risk factor for the development of not only eating disorders ${ }^{(19)}$ but also anxiety and depression disorders ${ }^{(20)}$. The signs were indicated in the children's statements of this study, who showed concern about gaining weight due to the possibility of being bullied at school or in the family environment. It generates reflection on the importance of strengthening the dialogue on these issues in the school environment and health services, in addition to the relevance of proposing strategies to promote the mental health of these children. 


\section{Limitations of the study}

The study had limitations since it was carried out in a border area located in the far north of Brazil, with peculiar characteristics, including the fact that it borders a French territory whose economy is largely based on tourism with Europe and mining, which differentiates it from other border regions of Brazil, making it impossible to generalize the data. In addition, the lack of studies evaluating the SDOHs that permeate the mental health of children in the border regions and the role of nurses in these places, made it impossible to further investigate the data.

\section{Contributions to the fields of Nursing, Health or Public Policy}

The results contribute to strengthening nursing practice and leadership in mental health promotion activities and proposing public policies, as they provide evidence on the impact of social determinants on children's mental health. Thus, these results can subsidize the actions and policies proposed by nurses in places where these determinants are also present to promote the strengthening of the sustainable development of this population.

\section{FINAL CONSIDERATIONS}

The study pointed out that the social determinants related to family abandonment, domestic violence, bullying, hunger, and child abuse were present in the French-Brazilian border region and closely related to the mental suffering reported by school children living in this place.

Therefore, children at the border are exposed to social determinants that leave them in a situation of greater individual vulnerability, at the mercy of an ineffective biopsychosocial development process, which may ultimately lead to the development of mental disorders.

\section{SUPPLEMENTARY MATERIAL}

Article from a Master's Dissertation of the Postgraduate Program in Health Science: Identification of psychopathological symptoms in schoolchildren from the Franco-Brazilian frontier and associated issues. Available from: http://repositorio.unifap. br/bitstream/123456789/112/1/Dissertacao_IdentificacaoSintomasPsicopatologicos.pdf

\section{REFERENCES}

1. World Health Organization. What are social determinants of health? [Internet]. Geneva: WHO; 2018[cited 2020 Feb 20]. Available from: https://www.who.int/social_determinants/en/

2. Krieger N. A glossary for social epidemiology. J Epidemiol Community Health. 2001;55(10):693-700. http://doi.org/10.1136/jech.55.10.693

3. Dahlgren G, Whitehead M. Policies and strategies to promote social equity in health: background document to WHO: strategy paper for Europe. Stockholm: Institute for Future Studies; 1991.

4. Fellmeth G, Rose-Clarke K, Zhao C, Busert LK, Zheng Y, Massazza A, et al. Health impacts of parental migration on left-behind children and adolescents: a systematic review and meta-analysis. Lancet. 2018;392(10164):2567-82. https://doi.org/10.1016/S0140-6736(18)32558-3

5. Shi J, Chen Z, Yin F, Zhao J, Zhao X, Yao Y. Resilience as moderator of the relationship between left-behind experience and mental health of Chinese adolescents. Int J Soc Psychiatry. 2016;62(4):386-93. https://doi.org/10.1177/0020764016636910

6. Almeida CS, Rauber AL. Oiapoque, aqui começa o Brasil: a fronteira em construção e os desafios do desenvolvimento regional. Redes. 2017;22(1):474-93. https://doi.org/10.17058/redes.v22i1.8532

7. Instituto Brasileiro de Geografia e Estatística. Séries históricas e estatísticas [Internet]. Rio de Janeiro: IBGE; 2018[cited 2020 Mar 20]. Available from: http://seriesestatisticas.ibge.gov.br/series.aspx?vcodigo=PD336

8. Bitsko RH, Holbrook JR, Ghandour RM, Blumberg SJ, Visser SN, Perou R, et al. Epidemiology and impact of health care provider: diagnosed anxiety and depression among US children. J Dev Behav Pediatr. 2018;39(5): 395-403. https://doi.org/10.1097/dbp.0000000000000571

9. Adhikari R, Jampaklay A, Chamratrithirong A, Richter K, Pattaravanich U, Vapattanawong P. The impact of parental migrationonthe mental health of children left behind. J Immigr Minor Health. 2014;16:781-9. https://doi.org/10.1007/s10903-013-9809-5

10. Telman MD, Overbeek MM, Schipper JC, Lamers-Winkelman F, Finkenauer C, Schuengel C. Family functioning and children's posttraumatic stress symptoms in a referred sample exposed to interparental violence. J Fam Violence. 2016;31:127-36. https://doi. org/10.1007\%2Fs10896-015-9769-8

11. Wilson L, Mendes IAC, Klopper H, Catrambone C, Al-Maaitah R, Norton ME, et al. 'Global health' and 'global nursing': proposed definitions from the global advisory panel on the future of nursing. J Adv Nurs. 2016;72(7):1529-40. https://doi.org/10.1111/jan.12973

12. Superti E, Silva GV. Integração internacional e políticas públicas de defesa e segurança na fronteira setentrional amazônica: reflexões sobre a condição fronteiriça amapaense. Intellector [Internet]. 2015[cited 2019 Oct 09];11(22):129-47. Available from: http://www.revistaintellector. cenegri.org.br/ed2015-22/superti-2015-22.pdf

13. Costa MA, Marguti BO, editores. Atlas da vulnerabilidade social nos municípios brasileiros. Brasília, DF: IPEA; 2015 [cited 2020 Oct 10]. Available from: http://ivs.ipea.gov.br/images/publicacoes/lvs/publicacao_atlas_ivs.pdf

14. Bittencourt MN, Vargas D. Construção e validação da escala de identificação de sintomas psicopatológicos em escolares (EISPE). J Bras Psiquiatr. 2017;66(2):65-72. https://doi.org/10.1590/0047-2085000000152 
15. Sousa AFL, Queiroz AAFLN, Oliveira LB, Valle ARMC, Moura MEB. Social representations of community-acquired infection by primary care professionals. Acta Paul Enferm. 2015;28(5):454-9. https://doi.org/10.1590/1982-0194201500076

16. Chiu M, Lebenbaum M, Cheng J, Oliveira C, Kurdyak P. The direct health care costs associated with psychological distress and major depression: a population-based cohort study in Ontario, Canada. PLoS One. 2017;12(9):e0184268. https://doi.org/10.1371/journal.pone.0184268

17. Strohschein L, Gauthier AH. Poverty dynamics, parenting, and child mental health in Canada. Soc Ment Health. 2017;8(3):231-47. https://doi. org/10.1177/2156869317731603

18. Naumann E, Tuschen-Caffier B, Voderholzer U, Schäfer J, Svaldi J. Effects of emotional acceptance and rumination on media-induced body dissatisfaction in anorexia and bulimia nervosa. J Psychiatr Res. 2016; 82:119-25. https://doi.org/10.1016/j.jpsychires.2016.07.021

19. Lie $S \varnothing$, Rø $\varnothing$, Bang L. Is bullying and teasing associated with eating disorders?: a systematic review and meta-analysis. Int J Eat Disord. 2019;52(5):497-514. https://doi.org/10.1002/eat.23035

20. Moore SE, Norman RE, Suetani S, Thomas HJ, Sly PD, Scott JG. Consequences of bullying victimization in childhood and adolescence: a systematic review and meta-analysis. World J Psychiatry. 2017;7(1):60-76. https://doi.org/10.5498\%2Fwjp.v7.i1.60 